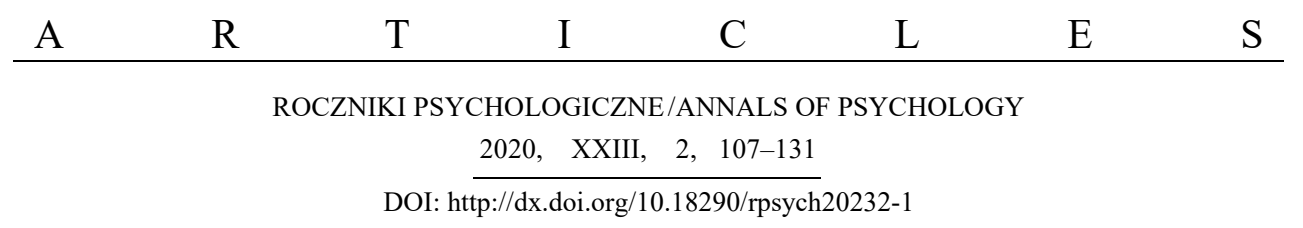

\author{
AMADEUSZ CITLAK \\ Institute of Psychology \\ Polish Academy of Sciences

\section{GROUP CONFLICTS IN LIGHT OF THE CRATISM THEORY (PSYCHOLINGUISTIC ANALYSIS)}

This article presents an analysis of intergroup relations in light of Władysław Witwicki's cratism theory. His theory allows social relations to be explained in light of the pursuit for a sense of power, although this has never been verified in the psychological laboratory. Because the cratism theory is largely based on the analysis of social relations described in historical documents, this paper presents an attempt to use its basic assumptions to describe the linguistic behavior (and linguistic picture of the world) of a threatened group. The examined material consisted of religious documents of the first Christians, created before and during the growing conflict with an unfriendly/ antagonistic environment. Frequency analysis shows significant changes in the cratic orientation as well as emotions and the evaluation of the social world in conflict conditions.

Keywords: cratism theory; Władysław Witwicki; Lvov-Warsaw School; inter-group conflicts; cultural-historical psychology.

Correspondence concerning this article should be addressed to AMADEUSZ CITLAK, PhD, Institute of Psychology, Polish Academy of Sciences, ul. Jaracza 1, 00-378 Warszawa, Poland; email: acitlak@wp.pl; ORCID: https://orcid.org/0000-0001-6550-1891.

This paper was prepared under the MINIATURE 2 project (funded by National Science Centre, Poland), no. 2018/02/X/HS6/00278). 


\section{INTRODUCTION}

\section{Inter-Group Relations and the Theory of Cratism}

Inter-group relations are of substantial significance to the most important problems of contemporary social psychology. The great interest in this area of psychology results not only from new methodological possibilities and accumulated theoretical knowledge but also from everyday needs and new challenges emerging from the change of sociocultural reality. The dynamics of group relations have been explained in light of many well-known theories, including: the authoritarian personality theory of Theodor Adorno (Adorno, 1950); Henri Tajfel's social identity theory (Tajfel, 1981, 1982); John Turner's theory of self-categorization (Turner, 1985); terror management theory (Greenberg et al., 1990); essentialism and entitativity in social cognition (Leyens et al., 2003). The psychoanalytical theories that were particularly popular in previous years have been replaced by research on social cognition or on motivated social cognition (Brown, 1995). Their main advantage is a solid empirical basis and a high degree of independence from cultural diversity.

In the case of Witwicki's theory of cratism, the situation looks different. First, it is a theory from the beginning of the 20th century, when complex empirical research (commonplace today) was not conducted in the field of psychology. Second, it is a theory that was developed on the basis of Witwicki's observations and announced in stages in 1900, 1907, and 1927. Today, it should be treated as an attempt that is more or less adequate to interpret and describe social reality. Third, as a student of Kazimierz Twardowski, the founder of the philosophical and logical Lvov-Warsaw School, Witwicki was primarily interested in the phenomenological description of mental phenomena (Rzepa \& Stachowski, 1993). At the beginning of the 20th century, the empirical psychological research conducted by Wilhelm Wundt in Leipzig did not raise much confidence in the milieu of Twardowski's students, especially with regard to the ability to understand the nature of psychological phenomena; Witwicki spent several months working with Wundt in Leipzig and he himself knew it well. Fourth, the cratism theory have never been experimentally verified, which is an amazing fact in the history of Polish psychology. The theory of cratism, after proper adaptation and verification, could be an alternative to the theory of striving for superiority by the Austrian psychologist Alfred Adler (Markinówna, 1935; Rzepa, 1991), and perhaps also a valuable complement to research in the field of social psychology. 
Despite the above-mentioned weaknesses of the cratism theory, I think that it still has some explanatory potential. Paradoxically, the value of the basic theses of this theory can be indirectly demonstrated by the works of Alfred Adler, Timothy Leary, or in Charles McClintock's research and studies, which are similar in many ways to Witwicki's works (Adler, 1920; Leary, 1957; McClintock, 1972). This potential is particularly evident when the theory of cratism is applied in the area of analysis within which Witwicki created his theory, i.e., on the basis of the analysis of historical written works. The theory was largely inspired and based on the analysis of social relations in the ancient world, which Witwicki attempted to reconstruct, mainly reading texts by Plato and Aristotle. In these historical works, he commented, among others, on the main motivational mechanism of human behavior: ambition and cratic desire. There is no need to discuss the theory in detail, as it is provided by psychological literature and is readily available (e.g., Jadczak, 1981, Rzepa, 1990, 1991, 1995; Citlak, 2016a, 2016b, 2019). However, I would like to point out a fact that I find particularly important. Due to the unique nature of the theory of cratism, particularly its creation on the basis of psychological analysis of ancient texts, we can assume that (if Witwicki carried out his research reliably) it not only describes social reality adequately but also allows for the socio-psychological changes taking place in that reality to be explained logically and consistently.

After the most important thesis of the cratism theory, the main motivational effort of people is cratic motivation, i.e., the need to be above others and themselves, as well as the aim of overcoming themselves, their own weaknesses, limitations, and acquiring competences. According to Witwicki, in ancient times, in a tribal environment, people pursued cratic aims through physical domination over others (Witwicki, 1900, 1927). However, as civilization progressed over time, they learned how to achieve power, domination or independence by acquiring complex social, professional and moral competences. The survival of the individual and the group became less and less dependent on physical strength and domination. There was a certain displacement in the area of social competition. Most likely, the perception of the social world and social cognition was increasingly less marked by physical strength and power, and social competition also changed as a result. Witwicki noted this kind of motivation in the ancient Greek (Witwicki, 1909/1999, 1904) and Semitic worlds (Witwicki, 1958), and in the religious community (Witwicki, 1927/1963, 1958).

The cratism theory also describes the emotional aspect of people's social behavior and allows social relations to be predicted (in a very general way) in light of the experienced sense of power. Witwicki made a simple classification 
of feelings on the basis of their dependence upon two variables: a person's hostile or friendly relation to us and the life force of this person (as perceived by us). This allowed Witwicki to distinguish six basic types of relationship and the social feelings prevailing in them, otherwise known as heteropathic emotions: ${ }^{1}$

- feelings towards stronger enemies (fear, anxiety)

- feelings towards enemies of equal strength (hatred, anger, hostility)

- feelings towards weaker enemies (contempt, disgust, disrespect)

- feelings towards stronger benevolent individuals (respect, admiration)

- feelings towards equal benevolent individuals (friendship, trust)

- feelings towards weaker benevolent individuals (compassion, pity).

The theory indicates two important variables ordering social relations: the pursuit of a sense of power and heteropathic emotions (Rzepa, 1995). The presented classification of six types of relationships can either be accepted or rejected. However, based on the analysis of historical sources performed by Witwicki and in the light of the issues raised in this paper, one should instead question the possible connection of the cratic motivation and heteropathic emotions with group processes. Do these variables play a role in group conflicts, and can they predict inter-group relations? Following Witwicki's considerations, such a connection seems to be very probable.

The important role of cratic motivation and cratic orientation in the processes of social change and the existence of social groups was demonstrated in research on the historical discourse of ancient Israel (Old and New Testament, see Citlak 2016c). Furthermore, the diminishing role of cratic orientation in communities with a more complex social organization was shown. However, the higher level of social organization was not only characterized by a lower level of cratic orientation but also co-occurred with a lower intensity of negative feelings (e.g., anger, contempt, hatred) and a higher intensity of positive feelings (e.g., compassion, admiration, trust). "The cratic orientation played a significantly greater role in the tribal and less socially diverse world. It turned out to be a psychological variable sensitive to socio-cultural changes ..., the variable sensitive to the type of discourse: results obtained in historical discourse were different than results obtained in legal discourse and epistolary literature. Its variability could also be noticed in a conflict situation in which the authors of the researched documents

${ }^{1}$ From the Greek language heteros (another, different) and pathos (feeling, experience). In contrast to these, Witwicki also speaks of autopathic feelings (Greek autos for "he" or "himself" and pathos for "experience" or "feeling") experienced in relation to oneself (Witwicki, 1927/1963). 
participated (passively or actively)."2 Therefore, "perhaps there is a relationship not only between the sense of psychological threat of the own religious group and the dogmatic and stereotypical thinking about strangers ... but also between the sense of psychological threat and cratic perception of the social world" (Citlak, 2016c, pp. 200, 178). The cratic orientation was understood there as the perception of the social world in terms of competition, hierarchy, domination and power. In this paper, I understand the cratic orientation in a similar way. ${ }^{3}$

\section{Cratic Orientation and Heteropathic Feelings in a Conflict Situation}

The proposition of the author's research results from the conclusions presented above. My reading of the antique and religious works induces me to believe that Władysław Witwicki aptly and very intuitively highlighted the important motivational mechanism of man, which was especially visible in the ancient world. It was also an achievement of the Polish psychologist to create a theory largely based on historical documents. For this reason, we can talk about Witwicki's historical or cultural-historical psychology and at least some part of his reflections that enter the area of historical social psychology, which has been underestimated for many years (Wundt, 1912; Gergen \& Gergen, 1984; Greenwood, 2003). In the research presented here I wanted to verify the hypothesis that a historical social group in conditions of conflict and a growing psychological threat should manifest changes in the cratic perception of the social world and in the intensity of the positive and negative emotions experienced. Contemporary empirical research allows us to draw conclusions about the emotions that we experience for in-group or out-group members, and this is a very rich tradition (the study of prejudice and stereotypes, categorization, essentialization, dehumanization, etc.). Therefore, I consider that indication of such dependencies (cratic perception and emotions under a psychological threat) on the basis of cratism theory may be an interesting input to current knowledge about group relations.

The cratic perception of the social world has not been the subject of research in the context of inter-group conflicts. However, based on social psychology, there is a rich and long tradition in which the main theses seem to be close to

\footnotetext{
${ }^{2}$ It is about historical sources created before the disintegration of the Israeli state and arising during its disintegration and during the period of servitude.

${ }^{3}$ I would like to point out that it is more about power in terms of coercion than in terms of the Foucauldian network.
} 
some of Witwicki's theses. Some of the older concepts include the authoritarian personality theory of Theodor Adorno (Adorno, 1950), the work of Erich Fromm (Fromm, 1973; Głogowska, 2016) on the sadomasochistic character, and the right-wing authoritarianism theory of Bob Altemeyer (Altemeyer, 1988, 2004). According to the above-mentioned theories, the driving force of human behavior is the tendency of absolute obedience to authorities with a simultaneous tendency of aggressive behavior towards enemies. The social dominance theory of Jim Sidanius and Felicia Prato (Sidanius \& Prato, 1999; Sidanius et al., 2004) is also similar; in this theory, the motive determining human social life is acceptance of the hierarchy, domination, rivalry and social inequality that usually justifies the use of violence and discrimination. It can be said that the category of power, domination or rivalry has a long empirical-theoretical line in social psychology. The very concept of cratism and the pursuit for a sense of power, although only partially covering them, can constitute an interesting extension of this tradition, especially when we associate the sense of power with a constellation of social feelings.

\section{RESEARCH MATERIAL}

The study includes quantitative analyses of the ancient discourse created in the communities of primitives Christians, specifically the original Greek text of the New Testament (Nestle \& Aland, 1994). These documents were chosen for three reasons. First, these are sources created in the context of the growing conflict between the first Christians and the pagan world. Second, they include materials that are consistent in terms of language and content and form a relatively coherent type of discourse. Third, these are ancient Semitic documents written under the influence of the Hellenistic culture, and thus they are the closest to the antique documents that Władysław Witwicki worked with (the Gospels and texts by Plato and Aristotle). The obtained results should create an adequate basis for comparisons and the possible verification of selected hypotheses of cratism theory.

The New Testament's documents were written in the second half of the first century. Although written by different authors, they were edited and corrected; some of them may even have come from the community of apostles' disciples (Koster, 1980; Kümmel, 1980; Fischer, 1985). They should be treated as works expressing community-group beliefs, not just individual convictions. At that time, the concept of the individual and the concept of "I" dissolved into the con- 
cept of "We"- the community or tribe (Markus \& Kitayama, 1991; Nisbett, 2003). It is also very difficult to talk about the individual/personal beliefs of the authors of these texts because the latter always manifest convictions of a religious group. The authors merely represented their community (Harre, 1998; Wolff, 1984).

These documents were to some extent analyzed independently of the content of religious and ethical beliefs contained in these texts. Although the books of the New Testament are usually subject to exegetical and theological examinations, in this case I deliberately departed from them so as not to get involved in theological or religious problems and remain exclusively in the context of psychological problems. Perhaps the conclusions from the obtained results could contribute to a better understanding of the nature of these texts, but this problem will not be discussed.

The research material included four texts:

1. Two corpuses of the New Testament epistolary literature: the so-called early and late epistles. The first of these were written from approximately AD 50 to 80. This is practically the entire Corpus Paulinum, which covers the letters of Saint Paul. ${ }^{4}$ The second group of late epistles are Catholic Epistles, created around the end of the first century. ${ }^{5}$ The division of epistles resulted from the commonly accepted division of epistolary literature suggested by historians and biblical scholars (Vielhauer, 1975; Kümmel, 1980; Köster, 1980). The early epistles arose when the new religion (religious movement) appeared at the heart of Judaism and was not subject to serious criticism and anxiety from the Roman authorities and the pagan world. It was a religious movement that had just created its first relations with the pagan community. Mutual relationships began to change in the last decades of the 1st century, when followers of official Judaism separated themselves from Christians and excluded them from the community. This process accelerated after the fall of the Jewish uprising in the seventies of the 1st century. In the late first century, the Roman authorities increasingly perceived Christians as a strange and dangerous sect against which protective measures had to be taken. This attitude resulted in persecutions during the reign

\footnotetext{
${ }^{4}$ For the purposes of the study, these are the Letters of Paul (1-2 to Thessalonians, 1-2 Corinthians, Galatians, Philippians, Romans, Ephesians, Colossians, Philemon, Titus, 1 Timothy). 2 Epistle to Timothy and the Epistle to Hebrews, according to the opinion of most biblical scholars, were written a bit later, and they were therefore included in the group of late letters.

${ }^{5}$ Epistle of James, 1-2 Peter, 1-3 Epistles of John, Epistle of Judah, 2 Timothy and the Epistle to the Hebrews. Regarding the time of creation of Epistle of James and 1 Peter, I am in favor of the contemporary critical position, according to which the two letters were most likely written after AD 70.
} 
of Emperor Nero, then Domitian and Trajan at the end of the 1st century. Early epistles, therefore, appeared in a period of emerging conflict and threat, and late epistles appeared in a period of tension and psychological threat to the identity and even existence of the Christian community.

2. Two types of narrative: historical (Gospel of Mark, Gospel of Matthew, Acts) and apocalyptic (Apocalypse of John). In this case, we also deal with documents that can also address the problem of inter-group relations. The Gospels describe the life of Jesus of Nazareth, while the Apocalypse focuses on the ultimate struggle between good and evil-a conflict of a universal and even cosmic nature. The concept of war, judgment and fighting between the faithful and unfaithful is one of the central axes of this book and is strongly represented within. Thus, the Gospels present a non-conflict historical narrative, while the Apocalypse presents a narrative conceived by universal and global conflict.

\section{METHOD}

\section{Method and Analysis}

Psychological research in the field of historical psychology cannot include experimental schemes or empirically verify causal connections. However, it can verify historical relationships (correlations) between variables as well as their historical variability (Dymkowski, 2003). One can also study the specificity and meaning of selected variables in their cultural and historical context, but these are qualitative studies. The present study is an example of quantitative analysis (Baker, 2006; Chung \& Pennebaker, 2007; Dalianis, 2018; Grimmer \& Stewart, 2013; Mehl, 2006; Zurloni et al., 2006) and above all represents historical discourse analysis, which is quite commonly used in psychological research on discourse (Brinton, 2015; Landwehr, 2009; Laudoa \& Vilanoub, 2015; Reisig1 $\&$ Wodak, 2009). Psychological research on religious discourse is currently gaining more and more attention (Abdou, 2015; Baker \& Vessey, 2018; Friedmann, 2008; Ingram, 2017; Stuckrad, 2015); this also applies to research on biblical texts (Ellens \& Rollins, 2004; Kille, 2005; Theissen, 2007). Today, there is a very significant and rich tradition of linguistic analysis, which after the domination of psychoanalytical theories, is clearly heading towards social psychology and social cognition (Czachesz, 2017; Hakola, 2008; Loumanen, 2011; Luomanen et al., 2007). 
This quantitative study also covers historical changes of variables; the independent variable is the emerging conflict between Christian communities and the infidels/foe, who were the real pagan world (or sometimes orthodox Jews) in the epistles, and an imaginary sinful world in the Apocalypse. In the case of historical and apocalyptic narrative, the type of narrative was also an independent variable. The dependent variable is the cratic orientation (perception of the world in terms of strength, power, domination, rivalry) as well as the intensification of positive and negative heteropathic feelings.

In the first phase, parts of the text were divided according to the time of their creation (early and late epistles) and according to the type of narrative (historical and apocalyptic). In the second phase, the four types of texts underwent frequency analysis, which is widely used in social and political psychology and sociology. This method, included in the mode of content analysis (Smith, 1996; van Dijk, 1997), consists in counting appropriately selected language elements taken from samples of the studied narratives (Baker, 2006; Kurcz, 2005; Pennebaker, 2007; see also Fairclough, 2001, Reisigl \& Wodak, 2009). Changes in the frequency of these elements usually indicate changes in the beliefs of their authors (Ertel, 1972, 1986). In our case, it was not just samples of texts that were considered (selected samples/fragments of the epistles and gospels), but the entire text collections were studied (all epistles and gospels) in order to increase the reliability of the obtained results. This method was also used in relation to ancient documents to obtain consistent results on social perception (see Citlak, 2007, 2015). The great advantage of frequency analysis is the ability to obtain numerical data on selected words and phrases that can be subjected to simple statistical calculations. As a result of this, one can obtain objective empirical material, allowing data accumulation and comparison of results. Frequency research is usually performed in two forms: as frequency-based dictionaries for a given language (or set of texts) - thanks to which the statistical data related to its vocabulary can be determined-or as frequency quotients/indicators, which include the proportions of selected language elements in texts compared to one another (Kurcz, 2005). Frequency quotients were used in the current study: the cratic orientation quotient and social feelings (heteropathic) quotient.

To measure the cratic orientation understood as the perception of the social world in terms of power, domination, submission, and asymmetry in social relations - the cratic quotient was used. The quotient included all Greek words in the texts referring to the concept of power, strength, domination, superiority, submission, etc. (e.g., strong, weak, servant, master, above, below, power, strength, weakness). The list of Greek cratic words was created in 2016 on the basis 
of W. Witwicki's works and his cratism theory (Citlak, 2016), and was corrected and refined by classical philologists in $2018 .^{6}$ In addition to all cratic words counted, the contexts in which they were used were verified. ${ }^{7}$ The numerical value of the quotient was calculated as the proportion of verses containing cratic expressions to the remaining verses forming the given text; the higher the value of the quotient, the higher the level of the cratic orientation.

The intensity of heteropathic feelings was measured by two quotients: one relating to positive feelings and the other to negative feelings. The values of the quotients were calculated as above: as the proportion of verses containing Greek words relating to positive or negative heteropathic emotions to the remaining verses forming the studied texts. Greek words were established by linguists on the basis of the list of Polish words developed in keeping with Witwicki's works. The division into positive and negative emotions is purely technical and does not relate to any evaluation of emotions. Generally, they can be divided into emotions typically experienced towards enemies (anger, hostility, contempt, fear) and towards members of the own or friendly group (love, friendship, pity, compassion). The negative/positive feelings quotient is therefore a general indicator, which primarily determines relations with regard to the in-group (own group) and out-group (strangers). It is difficult to say how much the Greek words agape (love), orge (anger), phobos (fear) etc. are close to the modern concepts of these emotions; however, the modern concepts seem closest to these words and certainly determine the nature of the relationship between the social subjects (persons or groups). Greek words were counted on the basis of context, not only on their appearance in the text corpus.

It should be added that the concept of emotions is a fairly fluid concept, in other words, it has a specific meaning in each culture and determines the way both behaviors and feelings or attitudes are experienced (Wierzbicka, 1994, 2006). Establishing such a meaning is a complicated task that requires detailed anthropological, linguistic, and cultural analysis. In comparison to the world of Judaism at that time, we know for sure that what we now call emotion had a slightly different connotation. The literature on the subject presents the German term Tun-Ergehen-Zusammenhang (Pieciul-Karmińska, 2007; Zenger, 1998), which means a close relationship between an act and the consequence of an act.

\footnotetext{
${ }^{6}$ I would like to thank the philologists Anna Szymańska PhD, Ewelina Górka PhD, and Dorota Samsonowicz for their assistance in creating the cratic terminology.

${ }^{7}$ For example, the Greek word epi (above) in the sentence "You will be above [epi] your enemies" was a diagnostic word, but in "Heaven is above [epi] the earth" it was irrelevant to my research.
} 
In the texts examined here, one cannot speak of an independent subject or person. In addition, "our current typology of emotions is not directly translatable or found in other languages or cultures" (van Cappellen, 2017, p. 258). The feelings in the ancient world had a slightly different character and did not necessarily refer only to internal states. Biblical language "ends to put less emphasis on the subjective feeling and more on the outward expression of the emotion, or in modern terms, its performance (...) verbs may not specifically refer to the subjective feeling of joy, but instead to its visible, audible, and physical expression" (van Cappellen, 2017, p. 258). The Greek language, however, has a rich lexicon related to emotions and is present in the New Testament texts, although - as I mentioned - it does not always coincide with the meaning of emotions in modern languages. In the quantitative analyses presented here, the attempt to capture changes in the area of feelings provides an opportunity to identify basic trends or relationships. But of course, they cannot be treated as a full or comprehensive analysis of the problem of the variation of feelings.

As a complement to the results of heteropathic feelings, the quotient of social world valuation was also used, which was counted as the proportion of positive or negative adjectives (used in the text to assess another person or social categories) to the remaining verses forming the studied text. The use of this third indicator was supposed to be an additional verification of the hypothesis that here, negative $v s$. positive social feelings actually mean the form of negative $v s$. positive attitude and valuation of the social world. In the construction of the first and second quotient, some conclusions of the expert linguist team presented in Relacje spoteczne świata antycznego w świetle teorii kratyzmu (Citlak, 2016c) were also used following their slight modification.

\section{Hypotheses}

According to the theory of cratism, the universal pursuit of man for the sense of power, superiority and independence is threatened by a conflict with a stronger group that holds a hostile attitude (in our case, the Roman Empire and the pagan world). It seems likely that people with a threatened cratic motivation and cratic view of the world will try to maintain or strengthen this motivation or view. Such a perspective of the world may also be increased, paradoxically, by the presence of a stronger enemy who becomes the personification of the world's order, i.e., through hierarchy, power and domination. Conflict with such an enemy should therefore enhance the cratic motivation. Altemeyer's authoritarianism and Sidanus' social dominance research also lead to similar conclusions: 
in a conflict situation, the need for hierarchy, domination and readiness to use negative stereotypes increases. Witwicki claimed that the endangered pursuit for a sense of power can be protected or recovered - especially when man "is subject to humiliation, oppression, insult" (Witwicki, 1907, p. 536) - in four different ways: humiliation of others, humiliation of himself, uplifting others, or uplifting himself. This is the most controversial moment of his theory because it makes it difficult to falsify a crucial thesis (any human behavior must be understood as cratic). I think, however, that the treatment of the existence of religious communities in antiquity just forced them to take the most radical decisions to increase their chances of survival. It seems very probable that among the four ways of sustaining a sense of power, only the raising of oneself and the humiliation of strangers play a decisive role. In my opinion, it is impossible that in those circumstances the threat to existence could, for example, give rise to a tendency to humiliate oneself. Furthermore, Witwicki also claimed that "any overt feeling of power gained over someone (...) elicits a similar need in another human being" (Witwicki, 1907, p. 536). In practice, this means that a persecuted and threatened religious community should demonstrate greater concentration in pursuit of a sense of power and a higher level of cratic orientation. Although Witwicki does not use the term "cratic orientation" in his works, I think that the cratic motivation should influence the perception of the world, and here I call that the cratic orientation. The first hypothesis was thus formulated as follows:

Hypothesis 1:

The value of the cratic quotient for late epistles is higher than that of early epistles (real conflict) and higher for apocalyptic literature (imaginary/anticipated conflict) than that of historical literature.

Anticipating differences in social feelings was quite easy because in the ancient world, especially in religious communities, outsiders were usually treated as infidels, strangers, and often as enemies and threats. The New Testament literature contains many extremely negative assessments of such people or social groups. The result was a quite unequivocal division of feelings: positive feelings are usually experienced towards the in-group members, but not towards strangers/enemies (usually out-group members). There were deviations from this pattern, but these were exceptions. In other words, the division of feelings into positive and negative feelings largely determined the boundary between the ingroup and out-group members. According to Witwicki's theory, the appearance of enemies (stronger, equal, weaker) increases the feelings of fear, anger, hatred 
and contempt, ${ }^{8}$ although it should not affect the changes of positive feelings (at least this is not predicted by the theory). However, such expectations are not evident if we take into account the uniqueness of the studied religious group and another psychological theory-terror management theory. In a situation of a threat to the status quo or to the existence of groups, they can be protected by using a natural buffer represented by their system of beliefs and values (Greenberg et al., 1990). In addition, it is worth noting that one of the most important values of the early Christian ethos was the principle of brotherly love and abandonment of aggression and hatred. Thus, although in light of the cratism theory one should expect the intensification of negative feelings, it is in light of the terror management theory (and in relation to the specific nature of the studied group) that the negative feelings could be pushed into the background. It is reasonable to expect the growth of positive feelings confirming the declared system of Christian values because these feelings built a sense of bond, integration and group mobilization.

Personally, I think that the ambiguity about the changes of negative emotions should be put into the wider cultural context of that time: the community was of paramount importance, typically subject to all ethical and religious principles. Something was considered to be worthwhile if it served the community's survival. Thus, I think that the negative reaction to enemies, that is, the concentration of negative feelings was an equally good means of protection with regard to the group ethos only. In connection with the above, the second hypothesis was formulated:

Hypothesis 2:

The late epistles and the apocalyptic narrative contain more negative feelings (negative feelings quotient) towards out-group members, as well as more positive feelings (positive feelings quotient) towards own-group members, compared to early epistles and historical narrative.

The anticipated differences in social feelings should be in line with a general tendency to evaluate the social world (one's own group and strangers). This is due to the simple fact that the experienced feelings are simply another form of evaluation of events or people. We usually use more positive than negative terms to refer to characteristics and categories that relate to loved or liked people. Thus, the third hypothesis was formulated:

\footnotetext{
${ }^{8}$ This position supports practically every major theory of social psychology: social identity theory, self-categorization theory, cognitive dissonance theory, essentialism and entitativity, etc.
} 
Hypothesis 3:

The late epistles and apocalyptic narrative contain a more negative valuation of enemies (negative evaluation quotient) and a more positive valuation of in-group members (positive evaluation quotient) in comparison to early epistles and historical narratives.

\section{RESULTS}

Cratic Orientation

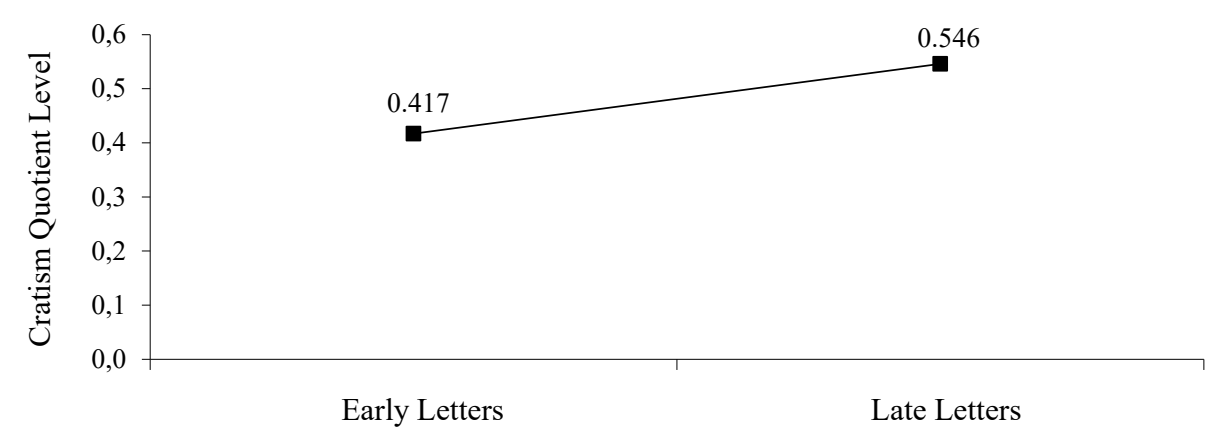

Figure 1. Level of Cratic Orientation in Epistolary Tradition

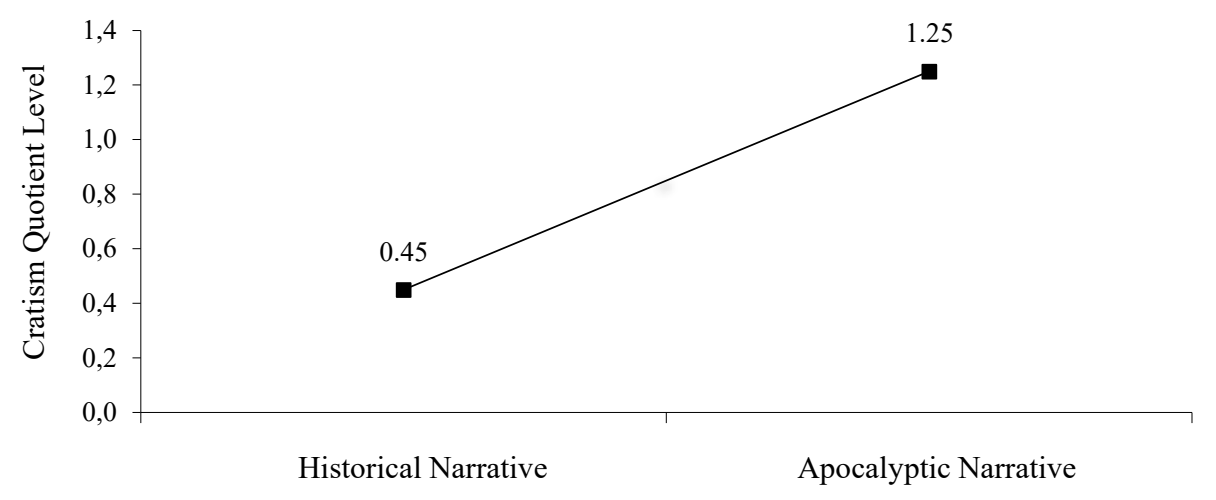

Figure 2. Level of Cratic Orientation in Historical and Apocalyptic Narrative 
The values of the cratic quotient for the late epistles and apocalyptic narrative are clearly higher, and the differences between the quotients are significant (the differences of proportions for epistles are: $\chi^{2}=9.56, d f=1, p<.01$; for historical $v s$. apocalyptic narratives they are: $\chi^{2}=93.96, d f=1, p<.001$ ).

\section{Social/Heteropathic Feelings \\ (Positive and Negative)}

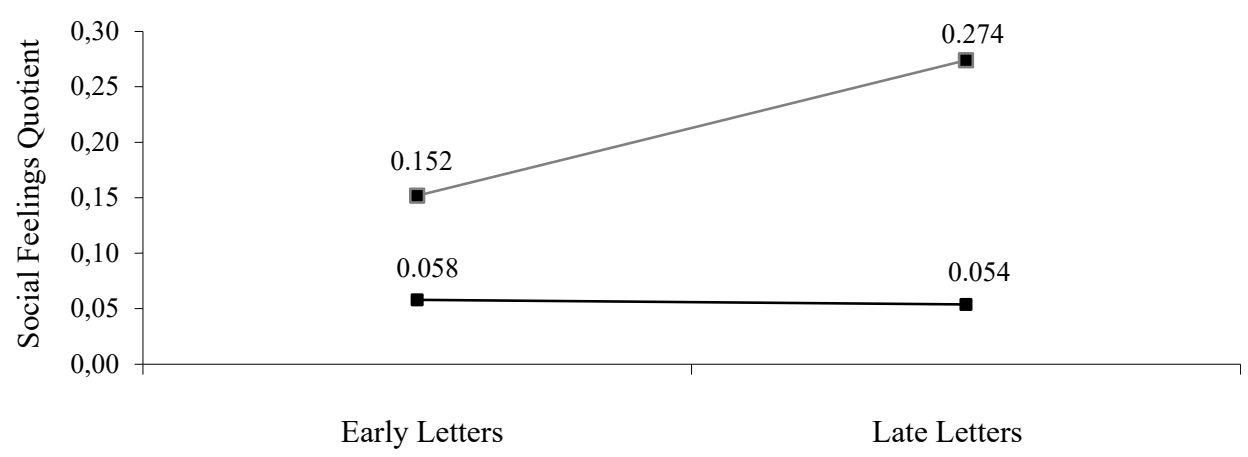

Figure 3. Intensity of Social Feelings in Epistolary Tradition

Note. The upper line refers to positive feelings and the bottom line to negative ones.

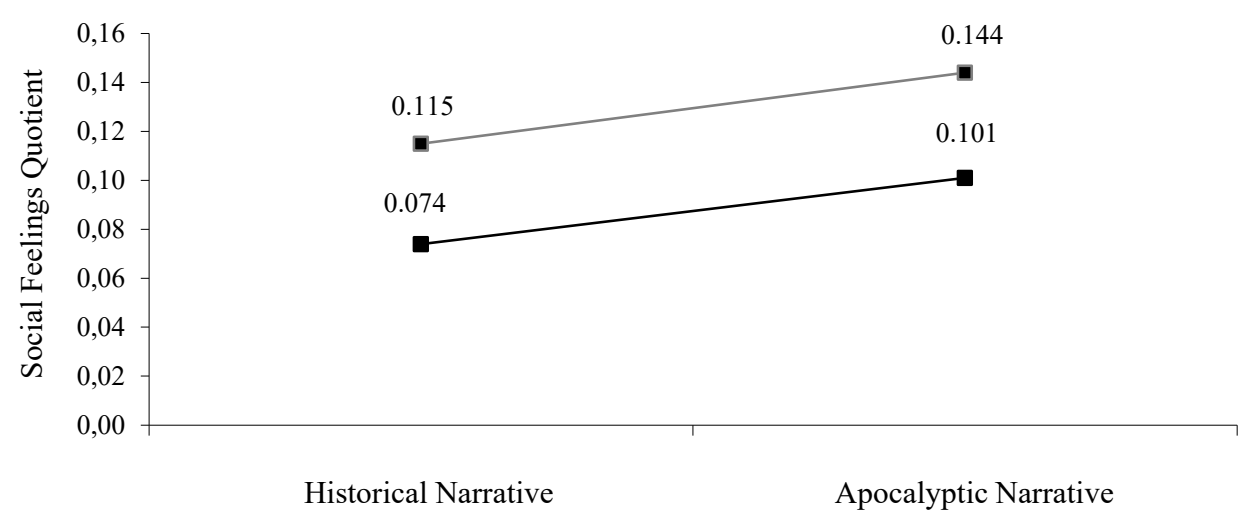

Figure 4. Intensity of Social Feelings in Historical and Apocalyptic Narrative

Note. The upper line refers to positive feelings and the bottom line to negative ones. 
The values of quotients in the late epistles are significantly different for positive feelings $\left(\chi^{2}=29.79, d f=1, p<.001\right)$, whereas for negative feelings they are not $\left(\chi^{2}=0.14\right)$. In the apocalyptic narrative, the quotient for positive feelings remains at a tendency level $\left(\chi^{2}=1.81, d f=1, p<.20\right)$ and are similar for negative feelings $\left(\chi^{2}=2.49, d f=1, p<.20\right)$.

\section{Evaluation of the Social World}

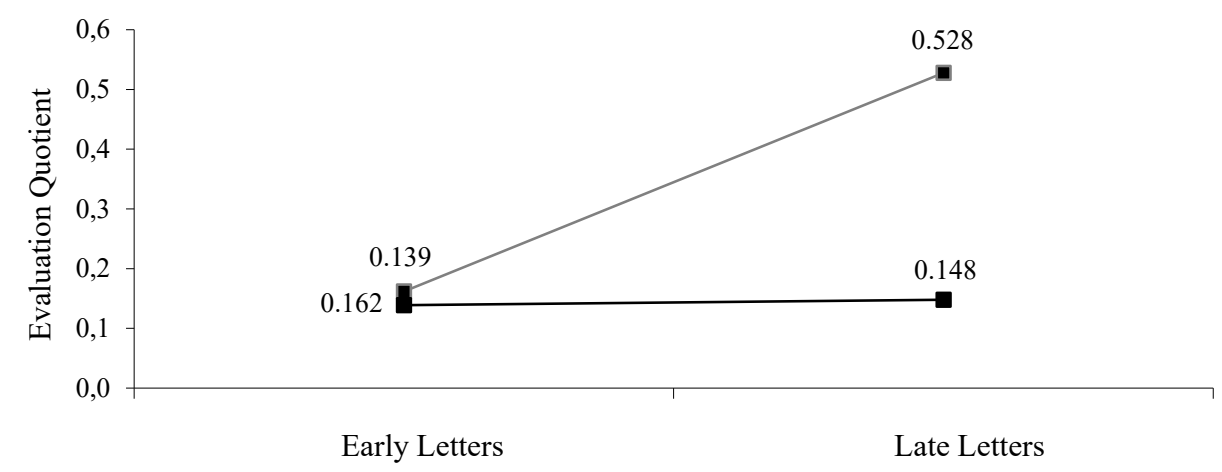

Figure 5. Evaluation of Social World in Epistolary Tradition

Note. The upper line refers to positive ratings and the bottom line to negative ones.

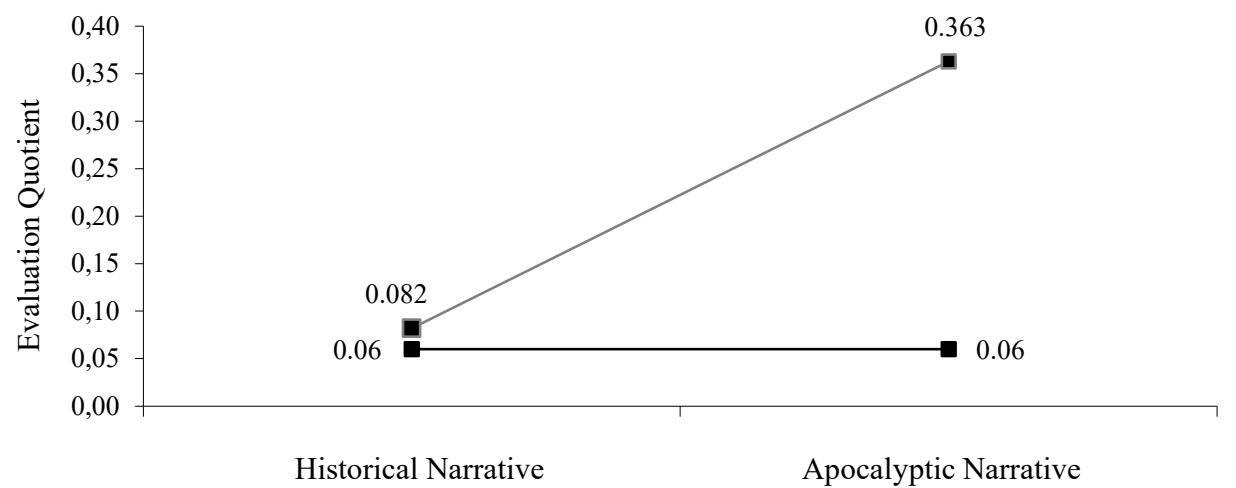

Figure 6. Evaluation of Social World in Historical and Apocalyptic Narrative Note. The upper line refers to positive ratings and the bottom line to negative ones. 
The values of quotients in the late epistles are significantly different for positive feelings $\left(\chi^{2}=155.72, d f=1, p<.001\right)$, while for negative feelings they are $\operatorname{not}\left(\chi^{2}=0.29\right)$. In the apocalyptic narrative the positive feelings quotient is significantly higher $\left(\chi^{2}=139.97, \mathrm{df}=1, p<0.001\right)$, whereas for negative feelings they are at the same level $\left(\chi^{2}=1.07\right)$. The chi-square test of independence also showed that there is a relationship between linguistic behavior (proportions for cratic orientation, feelings, and social evaluations) and the type of narrative (historical, epistolary, apocalyptic), although the intensity of the relationship as calculated by V Cramer is 0.11 .

The attempt to establish a correlation between variables (cratic orientation, positive/negative feelings, positive/negative social evaluations) obtained in all twenty six text units of the New Testament-without dividing them into text groups - showed a significant positive correlation between the cratic orientation level and the intensity of negative feelings $(r=0.575, p<.05)$, and the intensity of negative feelings with the intensity of negative $(r=0.588, p<.05)$ and positive $(r=0.573, p<.05)$ social evaluations.

\section{INTERPRETATION AND CONCLUSIONS}

The obtained results confirmed Hypothesis 1 about higher cratic orientation, both in the epistolary literature and the apocalyptic narrative (Figures 1 and 2). This allows us to draw several conclusions. First, cratic orientation has been shown to be sensitive to socio-psychological circumstances, and it is higher in conditions of psychological threat and group conflict (i.e., it results in a higher level of cratic orientation). Second, cratic orientation intensifies not only in conditions of real conflict and danger but also in the phase of anticipating and imagining conflict (see apocalyptic narrative). Third, it seems to depend on the type of discourse and language practices, as shown by the different level of quotients for different types of literature. This seems understandable if we take into account the fact that the type of discourse always remains in relation to sociopsychological determinants (Fairclough, 1992; van Dijk, 1997). It can be said that cratic orientation is not only different in different types of socio-religious groups (Citlak, 2016c) but it is also higher in conditions of psychological threat and inter-group conflicts.

Verification of Hypothesis 2 requires a broader discussion. It was confirmed but only the positive feelings quotient in the late epistles was higher than expected. This means that the higher frequency of these emotions in the literature 
was created in conditions of a growing conflict with strangers, specifically pagans. However, the negative feelings quotient towards enemies is almost at the same level, which seems incomprehensible in light of the cratism theory. The presence of enemies should trigger more negative emotions; this is even more the case with the epistles as they are characterized by a higher cratic quotient. Similar linguistic changes take place in the apocalyptic literature, in which the thematic axis is the global/final conflict between good and evil: these are similar changes in the sense that there are higher frequencies of positive feelings (although they are not statistically significant) and higher frequencies of negative feelings (without significant differences). Comparing the results presented in Figures 3 and 4, we can assume that we are dealing with a higher intensity of positive feelings and a lower intensity of negative ones. This result remains inexplicable in light of Witwicki's theory.

However, with regard to the higher frequency of positive emotions, it should be remembered that it is basically about the positive emotions about the same community members and not against enemies. Perhaps this was a practice that strengthened the sense of community ties and increased the chance of dealing with the threat. The higher quotient in the positive emotions may simply reflect group mobilization and the tightening of intra-group relations. However, if this was the case, then the tightening of group ties would occur in a broader psychological perspective in which the groups in question were located (i.e., in conditions of danger) and this would intensify negative feelings towards the threatening enemy (unfortunately, we did not observe these changes). This inconsistency of results becomes understandable if we refer to another theory of social psychology, especially to the aforementioned terror management theory of Greenberg, Pyszczynski, and Solomon (Greenberg et al., 1990; Greenberg et al., 1992). A higher frequency of positive emotions can be coherently and sensibly explained as a way of dealing with the threat by members of the religious community by invoking the professed system of values. The principle of love, forgiveness, mercy and renunciation of hatred, anger, violence and revenge are an essential part of that system. In practice, the Christian communities were (theoretically) able to focus more on the system of beliefs that increased positive emotions and inhibited negative emotions in conditions of danger.

Despite the lack of differences in negative feelings in the four groups of texts, the analysis of correlations for all proportions obtained in all twenty-six text units (gospels, epistles, Acts) showed a relatively strong correlation $(r=0.575)$ between the level of cratism and the intensity of negative feelings. This result suggests that the high level of cratic orientation is related to the nega- 
tivization of social relations and hinders rather than facilitating the development of such relations. ${ }^{9}$ This result also seems to be close to the thesis that with the development of social structures and the complexity of social organization, cratic orientation decreases; it is not conducive to building complex and stable interpersonal relationships that necessitate living in a group (Citlak, 2016c).

The values of the positive and negative feelings quotients are also similar to the results shown in Figures 5 and 6 . There are almost identical differences in epistolary and apocalyptic literature: a significantly higher quotient with regard to the proportions of positive adjectives and almost the same negative adjective quotient. Again, it is difficult to explain these changes in light of the cratism theory, but they are explained quite well by the terror management theory. The negative assessment of strangers fades into the background because the protection of the endangered community was primarily due to its belief system, which promotes positive feelings and abstains from hatred or aggression against enemies. Also, in this case we have a partial confirmation of Hypothesis 3. Regardless of whether these results may be coherently explained in light of the cratism theory or terror management theory, it is worth adding that in the case of ancient languages, the position of the adjective was slightly different than in modern languages. Adjectival forms were very often in close relation to verbal forms and were often used to express activities and their specificity. The assessment of people or behaviors through the use of adjectives typical for modern languages (good, bad, pure, holy, etc.) did not always play such an important role. The intensity of negative evaluations did not necessarily involve a more frequent use of negative adjectives but, for example, a more frequent use of semantically broader noun categories that denote entire moral, religious and ethical categories (evil, goodness, purity, sanctity, etc.). In short, the lack of differences in the use of negative adjectives does not necessarily imply that there is no negative evaluation because these changes could have occurred under other language categories that are not analyzed here. This problem was shown by other studies on early Christian discourse, where changes in the evaluation of enemies were visible partly in the context of used adjectives and partly in the context of used nouns (Citlak, 2014, 2015). However, this would require additional analysis.

The similarity of results obtained for heteropathic feelings (Figures 3,4) and social evaluations (Figures 5,6) permits another observation. The intensification of positive feelings clearly goes hand in hand with the intensification of positive

\footnotetext{
${ }^{9}$ A low level of cratic orientation and a high level of (selected) positive heteropathic feelings were obtained for Christ's speeches in the Gospels, see Citlak (2019).
} 
social assessments in the form of features attributed to social beings. I think that this is an important result for possible attempts to use the theory of cratism in the mainstream of social cognition. The application of the division of emotions presented by Witwicki based on the pursuit for a sense of power seems to be a useful way to analyze social relations, although its simplicity and generality should be combined with other methods of measuring such relations. The study presented here was supplemented by the analysis of adjectival forms commonly used by social psychologists in the study of stereotypes and group relations (Maass \& Arcuri, 1992; Wigboldus et al., 2000; Wojciszke, 2005). I expected such analogies, although it must be added that the correlation analysis indicated a relatively strong correlation only between negative emotions and negative adjectives. Nevertheless, it is quite an interest to combine the division of Witwicki's heteropathic emotions with the processes of social assessment or social cognition. The problem of mutual relations between cognition and emotions has a rich theoretical and empirical tradition in social psychology. One of the most interesting attempts at integration can be seen, for example, in the Stereotype Content Model (Fiske et al., 2002; Cudy et al., 2007). Certain analogies in the manner of the combination of psychological variables as well as the nature of these variables (social status and competition vs. co-operation) could facilitate a better understanding of the relationship between variables introduced by the Polish psychologist.

In closing the interpretation of the results, we can of course question to what extent it confirms Witwicki's theory of cratism. It must be remembered that an attempt to verify selected hypotheses of this theory is an attempt to modify it, because Witwicki left open the question of detailed connections between such variables as cratic desires and heteropathic emotions. Similarly, he never translated certain psychological concepts into empirical language. In other words, a verification attempt would also be a modification attempt. Additionally, in our study, the concept of cratism was understood as the cratic orientation and did not include - as mentioned earlier in this article-four different cratic desires: humiliation of others, humiliation of oneself, uplifting others or uplifting oneself. However, this modification was a necessary procedure for the analysis of intergroup relations.

In summary, there is no doubt that cratic orientation played a significant role in group processes and perhaps even determined social evaluations and the type of feelings that were experienced. These conclusions fit well into the historical reality; they allow a coherent and understandable explanation of the changes in the discourse created by the endangered religious community. I think that this is 
an important argument confirming the validity of Witwicki's statements, especially when we use them to analyze social relations on the grounds of culturalhistorical psychology.

\section{REFERENCES}

Abdou, E. (2015). 'Confused by multiple deities, ancient Egyptians embraced monotheism': Analysing historical thinking and inclusion in Egyptian history textbooks. Journal of Curriculum Studies, 48(2), 226-251.

Adler, A. (1920). Praxis und Theorie der Individualpsychologie [Practice and theory of individual psychology]. J. F. Bergmann.

Adorno, Th. W., Frenkel-Brunswik, E., Levinson, D. J., \& Sanford, R. N. (1950). The Authoritarian Personality. Harper \& Row.

Altemeyer, B. (1988). Enemies of freedom: Understanding right-wing authoritarianism. JosseyBass.

Altemeyer, B. (2004). Highly dominating, highly authoritarian personalities. The Journal of Social Psychology, 144(4), 421-447.

Baker, P. (2006). Using corpora in discourse analysis. Continuum.

Baker, P., \& Vessey, R. (2018). A corpus-driven comparison of English and French Islamist extremist texts. International Journal of Corpus Linguistics, 23(3), 255-278.

Brinton, L. (2015). Historical discourse analysis. In D. Tannen, H. Hamilton, \& D. Schiffrin (Eds.), The Handbook of Discourse Analysis (2nd ed., pp. 222-243). Wiley-Blackwell.

Brown, R. (1995). Prejudice. Its Social Psychology. Blackwell.

Chung, C. K., \& Pennebaker, J. W. (2007). The psychological function of function words. In K. Fiedler (Ed.), Social communication: Frontiers of social psychology (pp. 343-359). Psychology Press.

Citlak, A. (2007). Spostrzeganie przestępców w warunkach zmiany społeczno-politycznej dawnego Izraela [Perception of criminals under conditions of social and political change in ancient Israel]. Studia Psychologiczne, 45(2), 21-35.

Citlak, A. (2014). Problem nadróżnicowania językowego grupy własnej i obcej w dokumentach historycznych [The problem of linguistic inter-group bias in historical documents]. Studia Psychologiczne, 52(2), 40-56.

Citlak, A. (2015). O możliwościach psychologicznej analizy tekstów antycznych [On the possibilities of psychological analysis of ancient texts]. MEANDER - Rocznik poświęcony kulturze antycznej, 120, 79-96.

Citlak, A. (2016a). O empirycznym wykorzystaniu teorii kratyzmu W. Witwickiego [On the empirical application of Władysław Witwicki’s theory of cratism]. Psychologia Społeczna, $39(4), 426-439$.

Citlak, A. (2016b). Lvov-Warsaw School: The forgotten tradition of historical psychology. History of Psychology, 19(2), 105-124.

Citlak, A. (2016c). Relacje społeczne świata antycznego w świetle teorii kratyzmu. Psychologia historyczno-kulturowa w szkole lwowsko-warszawskiej [Social relations of the ancient world in light of the theory of cratism. Historical-cultural psychology at the Lvov-Warsaw School]. Instytut Psychologii PAN. 
Citlak, A. (2019). The concept of "cratism" and "heteropathic feelings" in the psychobiography of Jesus from Nazareth (psychobiography in Lvov-Warsaw School). In C. Helen-Meyer \& Z. Kovary (Eds.), New Trends in Psychobiography (pp. 381-403). Springer.

Cuddy, A., Fiske, S., \& Gluck, P. (2007). The BIAS map: Behaviors form intergroup affect and stereotype. Journal of Personality and Social Psychology, 92(4), 631-648.

Czachesz, I. (2017). Cognitive science and the New Testament: A new approach to early Christian research. Oxford University Press.

Dalianis, H. (2018). Computational methods for text analysis and text classification. In H. Dalianis, Clinical text mining (pp. 83-96). Springer.

Dymkowski, M. (2003). Wprowadzenie do psychologii historycznej [Introduction to historical psychology]. GWP.

Ellens, H., \& Rollins, W. (2004). Psychology and Bible. A new way to read the Scriptures (Vols. 1-4). Praeger Publishers.

Ertel, S. (1972). Erkenntnis und Dogmatismus. Psychologische Rundschau, 13, 241-269.

Ertel, S. (1986). Language, Thought and Culture: Toward a mergence of diverging problem fields. In I. Kurcz, G. W. Shugar, \& J. H. Danks (Eds.), Knowledge and language (pp. 139-163). North Holland.

Fairclough, N. (1992). Discourse and social Change. Cambridge: Polity.

Fairclough, N. (2001). Critical discourse analysis as a method in social scientific research. In R. Wodak \& M. Meyer (Eds.), Methods of Critical Discourse Analysis (pp. 121-138). London: Sage.

Fischer, K. M. (1985). Das Urchristentum. Evangelische Verlagsanstalt.

Fiske, S., Cuddy, A., Glick, P., \& Xu, J. (2002). A model of (often mixed) stereotype content: Competence and warmth respectively follow from perceived status and competition. Journal of Personality and Social Psychology, 82(6), 878-902.

Friedmann, M. (2008). Religious fundamentalism and responses to mortality salience: A quantitative text analysis. The International Journal for the Psychology of Religion, 18(3), $216-237$.

Fromm, E. (1973). The anatomy of human destructiveness. Holt, Rineheart and Winston.

Gergen, K., \& Gergen, M. (1984). Historical Social Psychology. Lawrence Erlbaum Associates Publishers.

Głogowska, E. (2016). On a sense of power, authority and escape from freedom. In J. Bobryk (Ed.), Language, values, actions: The Lvov-Warsaw School and selected problems of modern psychology, semiotics and philosophy (pp. 197-218). Polish Academy of Sciences.

Greenberg, J., Pyszczyński, T., Solomon, S., Rosenblatt, A., Veeder, M., Kirkland, S., \& Lyon, D. (1990). Evidence for terror management theory II: The effects of mortality salience on reaction to those who threaten or bolster the cultural worldview. Journal of Personality and Social Psychology, 58(2), 308-318.

Greenberg, J., Simon, L., Pyszczynski, T., Solomon, S., \& Chatel, D. (1992). Terror management and tolerance: Does mortality salience always intensify negative reactions to others who threaten one's worldview? Journal of Personality and Social Psychology, 63(2), 212-220.

Greenwood, J. (2003). Wundt, Völkerpsychologie, and experimental social psychology. History of Psychology, 4(1), 60-78.

Grimmer, J., \& Stewart, B. (2013). Text as data: The promise and pitfalls of automatic content analysis methods for political texts. Political Analysis, 21(3), 267-297. 
Hakola, R. (2008). Social identity and a stereotype in the making: The Pharisees as hypocrites in Matt 23. In B. Holmberg \& M. Winnige (Eds.), Identity Formation in the New Testament. Wissenschaftliche Untersuchungen zum Neuen Testament 227 (pp. 123-139). Mohr Siebeck.

Harre, R. (1998). The singular self: An introduction to the psychology of personhood. Sage.

Ingram, H. (2017). An analysis of inspire and Dabiq: Lessons from AQAP and Islamic State's propaganda war. Studies in Conflict \& Terrorism, 40(5), 357-375.

Kille, A., Psychological dynamics of the Bible in Jewish/Christian conflict. Pastoral Psychology, 53(4), 291-301.

Köster, H. (1980). Einführung in das Neue Testament [Introduction to the New Testament]. Walter de Gruyter.

Kümmel, W. G. (1980). Einleitung in das Neue Testament [Introduction to the New Testament]. Walter de Gruyter.

Landwehr, A. (2009). Historische Diskursanalyse [Historical analysis of discourse]. Campus.

Laudoa, X., \& Vilanoub, C. (2015). Educational discourse in Spain during the early Franco regime (1936-1943): Toward a genealogy of doctrine and concepts. Paedagogica Historica: International Journal of the History of Education, 51(4), 434-454.

Leary, T. (1957). Interpersonal Diagnosis of Personality. Ronald.

Leyens, J. P., Cortes, B., Demoulin, S., Dovidio, J. F., Paladino, M. P., Rodriguez-Perez, A., Rodriguez-Torres, R., \& Vaes, J. (2003). Emotional prejudice, essentialism and nationalism: The 2002 Tajfel lecture. European Journal of Social Psychology, 33(6), 703-717.

Luomanen, P., Pyysiainen, I., \& Uro, R. (2007). Explaining Early Judaism and Christianity: Contributions from Cognitive and Social Science. Brill.

Luomanen, P. (2011). Cognitive Science in Biblical Studies: An Overview. Collegium Biblicum, $15,15-32$.

Maass, A., \& Arcuri, L. (1992). The role of language in the persistence of stereotypes. In G. Semin \& K. Fiedler (Eds.), Language, interaction, and social cognition (pp. 129-143). Sage.

Markus, H., \& Kitayama, Sh. (1991). Culture and the self: Implications for cognition, emotion, and motivation. Psychological Review, 98(2), 224-253.

McClintock, Ch. (1972). Social motivation-A set of propositions. Behavioral Science, 17(5), 438-454.

Markinówna, E. (1935). Psychologia dążenia do mocy. Zestawienie poglądów Witwickiego i Adlera [The psychology of striving for power. A comparison of Witwicki's and Adler's views]. Kwartalnik Psychologiczny, 7, 329-340.

Mehl, M. R. (2006). Quantitative text analysis. In M. Eid \& E. Diener (Eds.), Handbook of multimethod measurement in psychology (pp. 141-156). American Psychological Association.

Nestle, E., \& Aland, K. (Eds.) (1993). Novum Testamentum Graece. Deutsche Bibelgesellschaft.

Nisbett, R. (2003). Geography of thought. Free Press.

Pieciul-Kamińska, E. (2007). Językowy obraz świata i Boga. O przekładzie teologii niemieckiej na język polski [The linguistic image of the world and God. On translating German theology into Polish]. Wydawnictwo Poznańskie.

Reisigl, M., \& Wodak, R. (2009). The discourse-historical approach. In R. Wodak \& M. Meyer (Eds.), Methods of critical discourse analysis (pp. 87-121). Sage.

Rzepa, T. (1990). Geneza, istota i konsekwencje teorii kratyzmu Władysława Witwickiego (18781948) [The origin, essence and consequences of Władysław Witwicki’s theory of cratism (1878-1948)]. Studia Philosophiae Christianae, 26(1), 221-234. 
Rzepa, T. (1991). Psychologia Władysława Witwickiego [Władysław Witwicki's Psychology]. Wydawnictwo Naukowe UAM.

Rzepa, T. (1995). Witwicki. Psychologia uczuć i inne pisma [Witwicki. The psychology of emotions and other writings]. PWN.

Rzepa, T., \& Stachowski, R. (1993). Roots of the methodology of Polish psychology. Poznan Studies in the Philosophy of the Sciences and the Humanities, 28, 233-250.

Sidanius, J., \& Prato, F. (1999). Social dominance: An intergroup theory of social hierarchy and oppression. Cambridge University Press.

Sidanius, J., Prato, F., van Laar, C., \& Levin, S. (2004). Social dominance theory: Its agenda and method. Political Psychology, 25(6), 854-880.

Smith, Ch. (1996). Content analysis. In A. Manstead \& A. Hewstone (Eds.), The Blackwell Encyclopedia of Social Psychology (pp. 125-130). Blackwell Publishers.

Stuckrad, K. (2015). Discursive study of religion: Approaches, definitions, implications. Method and Theory in the Study of Religion, 25(1), 5-25.

Tajfel, H. (1981). Human groups and social categories: Studies in social psychology. Cambridge University Press.

Tajfel, H. (1982). Social identity and intergroup relations. Annual Review of Psychology, 33(1), $1-39$.

Theissen, G. (2007). Erleben und Verhalten der ersten Christen. Eine Psychologie des Urchristentums [Experience and behavior of the first Christians. A psychology of early Christianity]. Gütersloher Verlagshaus.

Turner, J. C. (1985). Social categorization and the self-concept: A social cognitive theory of group behavior. In E. J. Lawler (Ed.), Advances in group processes: Theory and research (Vol. 2, pp. 77-122). JAI Press.

Van Cappellen, P. (2017). Rethinking self-transcendent positive emotions and religion: Insights from psychological and biblical research. Psychology of Religion and Spirituality, 9(3), 254-263.

Van Dijk, T. (1997). The study of discourse. In T. van Dijk (Ed.), Discourse as structure and process (pp. 1-34). Sage.

Vielhauer, Ph. (1975). Geschichte der urchristlichen Literatur [History of early Christian literature]. Walter de Gruyter.

Wierzbicka, A. (1994). Emotions, language and "cultural scripts." In S. Kitayama \& H. Markus (Eds.), Emotion and culture: Empirical studies of mutual influence (pp. 130-162). American Psychological Association.

Wierzbicka, A. (2006). Emotions across languages and cultures: Diversity and universals. Cambridge University Press.

Wigboldus, D. H. J., Semin, G. R., \& Spears, R. (2000). How do we communicate stereotypes? Linguistic biases and inferential consequences. Journal of Personality and Social Psychology, 78(1), 5-18.

Witwicki, W. (1900). Analiza psychologiczna ambicji [Psychological analysis of ambition]. Przeglad Filozoficzny, 3, 26-49.

Witwicki, W. (1904). Analiza psychologiczna objawów woli [Psychological analysis of the symptoms of will]. Archiwum Naukowe, 2, 1-27.

Witwicki, W. (1907). Z psychologii stosunków osobistych [From the psychology of personal relationships]. Przegląd Filozoficzny, 10(4), 531-537. 
Witwicki, W. (1909). Introduction and notes. In Plato, Uczta [Symposium] (W. Witwicki, Trans.). Księgarnia Polska B. Połonieckiego.

Witwicki, W. (1927/1963). Psychologia [Psychology] (Vol. 2). PWN.

Witwicki, W. (1958). Dobra Nowina wg Mateusza i Marka. [The good news according to Matthew and Mark]. PWN.

Wojciszke, B. (2005). Affective concomitants of information on morality and competence. European Psychologist, 10(1), 60-70.

Wolff, H. W. (1984). Anthropologie des Alten Testaments [Anthropology of the Old Testament]. Gütersloher Verlagshaus, Kaiser Chr. Verlag.

Wundt, W. (1912). Elemente der Völkerpsychologie [Elements of Völkerpsychologie]. Kröner.

Zenger, E. (1998). Einführung in das Alte Testament [An introduction to the Old Testament]. Kohlhammer.

Zurloni, V., Anolli, L., \& Riva, G. (2006). Linguistic intergroup bias in political communication. Journal of General Psychology, 133(3), 237-255. 